\title{
Definition of Inflammation, Causes of Inflammation and Possible Anti-inflammatory Strategies
}

\author{
Srđan V. Stankov*
}

Pasteur Institute Novi Sad, Hajduk Veljkova 1, 21000 Novi Sad, Serbia

\begin{abstract}
Current definition of inflammation by its cardinal signs is obsolete and unsuitable for guiding adequate therapeutic strategies. Furthermore, present theory of the inflammatory process regarding vascular phenomena as essential for generation of cardinal signs is invalid and unable to explain well established empirical facts, particularly the extent of the osmotic pressure and temperature variations within the inflamed tissue.

From five cardinal signs, there is actually just one specific macroscopic sign of inflammation, namely localized edema. Further, the driving force for tissue fluid accumulation is defined in biochemical terms and as such taken for the definition of the inflammatory process. Inflammation may be defined as a degenerative process which is intense enough to cause local accumulation of low molecular weight catabolic products, which in turn elevates tissue osmotic pressure that attracts extra fluid, with or without heat release sufficient for significant elevation of tissue temperature. This process is in a sharp contrast to the pathogenesis of burns, where externally applied heat causes a process that is in essence opposite to inflammation, bearing only some superficial similarities with the latter.
\end{abstract}

The inflammatory process is itself a pathological process, whereas the natural anti-inflammatory response that ensues after acute inflammation tends to reverse tissue homeostasis towards normality and should therefore be regarded as a true defensive reaction of the affected tissue.

Based on the therapeutic principle of reverse thermodynamics, heat application to the inflamed tissue is an obvious, yet non-exclusive therapeutic choice that follows from the given universal definition of inflammation.

Keywords: Inflammation, catabolism, osmotic pressure, edema, anti-inflammatory response, burns.

\section{INTRODUCTION}

Biological objects in life sciences are often observed and described while taking part in processes with various, sometimes even directly opposite outcomes, whereby these processes are named identically and according to the object concerned. For example, "activity of lactate dehydrogenase" is a name for a process that in reality includes both the oxidation of lactate to pyruvate and also its reverse process, reduction of pyruvate to lactate. Similarly, "phagocytosis" denotes a process of engulfment and full digestion of bacteria by a phagocyte but also a process of engulfment of bacteria by a phagocyte followed by reproduction of bacteria with resultant phagocyte lysis, i.e."eating" the host cell by bacteria $[1,2]$. On the organismal scale, the classical meaning of "immunity" has been resistance to influences of infectious agents, meaning in reality absence of inflammation in presence of a pathogenic microorganism. However, one of the classical experimental models of causing inflammation is application of complete Freund adjuvant (CFA), that is generally regarded as one of the strongest immunostimulators [3]. Thus, by "immunity" one usually understands both absence of inflammation as

*Address correspondence to this author at the Pasteur Institute Novi Sad, Hajduk Veljkova 1, 21000 Novi Sad, Serbia; Tel: +381 21 6611003; Fax: +381 216611003 ; Emails: stankov.paster@gmail.com,

Stankov.paster@ptt.rs apparent tolerance to microorganisms, and also vigorous inflammation, i.e. hypersensitivity to noxious stimuli. Wide variety of ambiguous terms in biology may be and often is an inspiration for further experimental and theoretical work and development of biological sciences. However, from a medical perspective ambiguous theoretical terms are a great obstacle because at one time and place, a process (physical, chemical or biological) may take only one direction. Therefore, in order to reliably predict the influence of a given defined factor to a biological environment, one should first unambiguously define its interaction with biological objects as a unidirectional process. For example, the biochemical term "hydrolysis" denotes only the process of disruption of bonds between monomeric units of biopolymers in presence of water and not vice versa. Since biochemical reactions between substrates generally satisfy this condition of unambiguousness, potential great benefits to medical sciences from explicitly defining biological processes in terms of biochemical reactions between substrates are here exemplified by a biochemical definition of the inflammatory process, an old, widely important but still controversial notion. Although the inflammatory process as a manifestation of disease has been recognized almost from historical beginnings of medicine, its nature and physiological significance have not become clear and undisputed until present time. Here are some characteristic opinions. "Most pathologists would probably agree that inflammation represents a response of living tissue to local 
injury..." [4] "Inflammation: A basic way in which the body reacts to infection, irritation or other injury, the key feature being redness, warmth, swelling and pain. Inflammation is now recognized as a type of nonspecific immune response." [5] "Inflammation is the basic process whereby tissues of the body respond to injury." [6] "Although we have learned a lot about the signaling pathways that link energy accumulation [adiposity] to chronic inflammation, we know little about the real biological significance of the inflammation." [7] At present, inflammation is defined by the presence of five macroscopic pathological phenomena, four of them proposed by Celsus as long as 2000 years ago. These are tumor swelling of the tissue, calor - elevated tissue temperature, rubor - blood color-like redness of vascularized tissue at the inflammation site, dolor - intensive sensation of a noxious stimulus, and functio laesa, i.e. impaired function of the organ affected [8, 9]. All signs have been regarded as secondary to one primary pathophysiological event enhancement of vascular permeability as a direct consequence of tissue injury [4, 10]. Meanwhile, modern natural sciences have comprehensively elucidated biological processes at the biochemical and molecular level that take place in the course of the inflammatory process. In the 1940s, American pathologist Menkin defined the sixth cardinal and at the same time the only essential biochemical sign of inflammation, i.e. proteolysis [11]. However, the significance of his discovery has been largely neglected, leaving considerable confusion in explanations of the causeeffect relationships in pathogenesis and in the approaches to treatment of inflammatory diseases [12]. In particular, it is very often noted that, although inflammation is a defensive, therefore a useful process, its exaggeration or prolonged action may harm the body. However, the reasons for such outcomes are never explicitly stated.

\section{DEFINITION OF INFLAMMATION}

\section{The Specificity of Cardinal Signs of Inflammation}

Now, let us first look at the phenomena that are truly specific to the inflammatory process. Of five classical signs, pain and loss of function are present also with a degenerative process. For example, both may be present when joints are affected either by arthritis or arthrosis. Further, redness may be present also with functional hyperemia, cutaneous tumors, hemangioma, polycythemia, burns, etc. Elevated tissue temperature may be observed with hyperthermia, burns or functional hyperemia. Finally, edema that encompasses major body parts appears with heart or kidney failure. That leaves us with only one truly specific sign of inflammation, i.e. localized edema. Increased vascular permeability per se, often indicated as the immediate cause of inflammatory edema [4, 10], cannot really be considered responsible for several lines of evidence as follows. First, low molecular weight (Mwt) substances account for the most part (over $98 \%$ ) of the osmotic pressure in the extracellular as well as the intracellular space [13]. Starling equation [14, 15], which considers only capillary hydrostatic and oncotic pressures and that is often used for explanation of tissue fluid dynamics under physiological conditions, may then obviously be inadequate in pathological conditions with significant changes of crystalloid concentration. Second, in physiological conditions there is a constant free flow, exudation of plasma into hepatic tissue, therefore such exudation cannot create any disbalance of oncotic forces and consequently cannot contribute to edema at least in hepatitis. Further, transcapillary exudation cannot explain appearances of cellular [16-19] and mitochondrial [20, 21] edema as primary phenomena in the course of inflammation. An obvious proof that any circulatory mechanism is completely unnecessary for inflammation is its appearance in avascular tissues, e.g. in the cornea [22, 23] or in cartilage [24, 25]. Looking at the development of experimental stromal keratitis it is obvious that disciform corneal edema might first appear on any part of the cornea, depending on the location of the effect of the irritant applied [22, 23]. This is in sharp contrast to first appearance of edema on the limbal area with subsequent spread to the corneal center, something one would expect had the edema been generated by changes in the nearest vasculature. From an evolutionary perspective, inflammation as represented by edema appears older than the blood circulatory system. Thus, swelling of perianal area upon infection by bacterium Microbacterium nematophilum in the nematode Caenorhabditis elegans [26], animal lacking any blood circulatory system, is a clear indication that inflammation may proceed in absence of both circulation and migratory cells. In early works investigating altered vascular permeability, exudation of plasma into the tissue was demonstrated by leakage of certain dyes, e.g. Trypan blue or Evans blue [4, 27], but little attention was paid to the actual appearance of edema, since between vascular leakage and edema a sign of equality was in principle understood. In these experiments, the injurious agent was typically heat, meaning that the pathological changes caused were burns, a process somewhat similar, but actually opposite to inflammation (see below). However, with burns there is also a significantly increased lymphatic flow [28], and it is therefore conceivable that in such cases increased capillary permeability may exist without edema. Circulatory mechanisms are also unable to explain the intensity of another important sign, calor. The classical explanation is that enhanced blood flow into the inflamed tissue elevates its temperature by heat conduction from the warmer blood to the affected tissue. In this case, the tissue temperature could be elevated only to the temperature of the blood, i.e. to the core body temperature. However, this concept has been convincingly refuted by Segale and his predecessors by observation of warmer venous in relation to arterial blood in the area of inflammation and by showing that the temperature difference between inflamed and healthy tissue actually increases upon circulatory arrest [29]. More recently, temperature measurements of inflamed oral mucosa [30] and also meticulous investigations of atherosclerotic plaques on interior walls of arteries [31-33] showed that the temperature may actually rise more than 2 degrees $C$ above the core level! Specifically, heating intensities in atherosclerotic plaques were well correlated with densities of neighboring macrophage infiltrates, showing that the only possible sources of heat in this case could have been either the metabolism of local cells or the biochemical reactions catalyzed by excreted cellular products.

\section{The Biochemical Definition of Inflammation}

The driving force for fluid accumulation may ultimately stem only from the actual tissue metabolic activity, the latter 


\section{ANABOLISM}

Monomers and lower Mwt substances + energy ===> polymers and higher Mwt Substances + water

Eq. (1)

\section{CATABOLISM}

\section{$<==$}

being an equilibrium between catabolic and anabolic processes under physiological conditions. This balance could generally be presented by the following equation:

Here, anabolism and catabolism are considered in their strict sense, not presenting processes concordant with or supportive of either of them, such as oxido-reductions or fermentations. These other processes should be classified as either catabolic or anabolic according to their influence upon Eq. (1) equilibrium through their impact on reaction reactants. In particular, oxidative reactions, although often considered as catabolic, should be regarded as principally anabolic, being the primary source of energy-rich compounds. Energy absorbed by anabolic reactions is usually conserved by energy-rich compounds such as ATP, while catabolic energy is released in form of heat, thereby bringing about maintenance of constant tissue temperature in homeoterms. Also, low molecular weight substances account for the most part of the tissue osmotic pressure elevation generated in the course of catabolism. Whenever is the metabolic balance sharply disturbed in favor of catabolism: a) osmotic pressure rises, attracting extra fluid into the tissue, edema; and b) free heat liberated from lytic and other exothermic reactions such as decarboxylation, desamination or glucose fermentation may significantly elevate tissue temperature on its way out of the body. This is a general mechanism that comprises phenomena of extracellular, cellular and mitochondrial edema. Thus, the inflammatory process may be defined as a condition of acceleration of tissue catabolism with such rate that 1) catabolism prevails over anabolism, and 2) rise in the osmotic pressure is fast enough to cause significant fluid accumulation with or without concomitant elevation of tissue temperature. Because a general prevalence of tissue catabolism over anabolism is also observed in degenerative processes, the distinction between inflammation and degeneration is based only on the actual intensity of the process. Elusive nature of difference between degeneration and inflammation has recently been clearly pointed out for the well studied case of joint degeneration conditions, which show that in joint cartilage mediators of inflammation are present with degeneration that cannot meet the classical criteria for inflammation [34]. Also, substances analogous to mediators of inflammation (primarily proteolytic enzymes) are induced by interactions of $C$. elegans with bacterial pathogens and not accompanied by classical signs of inflammation, but with clear noxious effects [35]. Therefore, so called "mediators of inflammation" should rather be called "mediators of degeneration" as they are able to mediate both inflammatory and non-inflammatory degenerative processes. For a simplified illustration of possible quantitative characteristics of the inflammatory process, let us first assume that catabolism is entirely represented by proteolysis, since proteins are the main components of the dry weight of lean tissue, where inflammation usually takes place. One $\mathrm{kg}$ of lean tissue contains on average about $200 \mathrm{~g}$ of proteins [36, 37], and taking $135 \mathrm{Da}$ for amino acid (AA) mol. wt. average
(117 Da for AA residue), about $1.7 \mathrm{M}$ AA residues are incorporated in proteins per $\mathrm{kg}$ of lean mass. Normal tissue fluid osmolarity is $300 \mathrm{mOsm} / \mathrm{L}$, or $0.3 \mathrm{Osm} / \mathrm{L}$ [13], that is the osmolarity of $0.3 \mathrm{M}$ of a nonionized substance. A noticeable effect of increased osmotic pressure is evident when the increase is about $50 \%$, namely to about 450 $\mathrm{mOsm} / \mathrm{L}[38,39]$. In order for tissue osmolarity to rise by $50 \%$, it is sufficient that $0.15 \mathrm{M} / 1.7 \mathrm{M}=8.5 \%$ of AA residues in proteins are liberated by proteolysis. On the other hand, normal tissue temperature variations are within $\pm 0.5^{\circ} \mathrm{C}$, and the average tissue heat capacity is $3.47 \mathrm{~kJ} / \mathrm{kg}{ }^{\circ} \mathrm{C}$ [13]. Thus, for a significant tissue temperature rise a heat release of at least $1.73 \mathrm{~kJ} / \mathrm{kg}$ appears to be necessary. Taking $13 \mathrm{KJ} / \mathrm{mole}$ as the average energy of peptide bond hydrolysis [40], about $0.13 \mathrm{M}$ AA has to be released from proteins, or at least $7.6 \%$ tissue protein should be hydrolyzed for this purpose. It appears that roughly the same proportion of protein $(8 \%)$ should be hydrolyzed in order for two major signs of inflammation, edema and heat, to emerge. Experimental studies with actual measurement of osmotic pressure in inflammatory edema have for example shown that it may rise by $37 \%$ [38] or up to $720 \%$ [41] in relation to control values, figures that could by no means be explained by Starling forces. The causative role of catabolism for generation of tissue hyperosmolarity in inflammation has so far been postulated by several authors [42- 44], but such statements and their practical significance seem to have been neglected by the scientific community. However, there are two additional important factors that actually determine tissue osmotic pressure and temperature. These are the rate of diffusion of lytic products from tissue for osmolarity and the rate of heat loss for tissue temperature. While the diffusion of lytic products may be significantly impaired by the accompanying stasis, the heat loss rate is usually unaffected. Therefore, edema may appear even in the absence of a noticeable calor. Dolor may be a result of a direct irritant action of the causative factor, of action by some mediators, or perhaps most commonly of direct mechanical pressure of edematous fluid on surrounding nerves. For example, lack of compliance of the dental pulp is an obvious reason for a most intense pain that is often experienced with dental caries. Finally, rubor would result from accumulation of red hemoglobin-containing erythrocytes in the course of vascular stasis and/or arteriolar dilatation. The presented definition is fully concordant with all classical macroscopic signs of inflammation. Should perhaps cellular infiltration, the histological hallmark of inflammation, or presence of a number of biochemically defined mediators be involved in a comprehensive definition of inflammation? This question should also be considered from its biochemical aspect. Although bearing a potentially important catalytic role, cells and individual mediators are still non-essential for the biochemical process concerned. So far, there appears to be no specific set of cells and mediators that would include each type and case of the inflammatory process. Summarizing the definition above, it follows that 
inflammation is a direct consequence of a tissue injury that shifts the metabolic balance towards catabolism. Manifestations of enhanced catabolism in the course of an inflammatory process may be proteolysis [45-50], diminution of cellular space volume [51] or diminished oxidative metabolism $[52,53]$. So it is a pathological process, not a defensive reaction. But what is at the origin of the common belief that inflammation represents a defensive mechanism?

\section{Interrelationship Between Inflammation, Anti-inflammatory Response and Burns}

Early investigators of inflammation in laboratory conditions observed the whole cascade of events upon the isolated application of an irritant to a living tissue [4, 54, 55] - This cascade also included, besides inflammation as a pathological process as a direct consequence of the factor applied, also the natural anti-inflammatory response, essentially characterized by proteolysis inhibition [56-58]. Anti-inflammatory response ensues after inflammation reaches its climax, and represents a true defensive response that should in neither case be mixed with or ascribed to the latter. This relationship between the inflammatory process and the true defensive response is analogous to the relationship between inorganic material compression upon mechanical pressure and the elasticity of the material. The latter phenomenon, partial restoration of volume and shape upon cessation of the external force, is the inherent property of the material and not the consequence of the force itself, hence in neither case the integral part of the process of compression. Each event observed upon tissue injury might be either a part of inflammation as a direct consequence of the injury, or a part of the anti-inflammatory response as a true defensive response of the host tissue. These two opposing processes may be and often are uncoupled in reality. Thus, inflammation with a dampened antiinflammatory response is present in cases of chronic inflammation, autoimmune diseases, hypersensitivity reactions etc. The most obvious reason for an exaggerated inflammation (or the prevalence of the pro-inflammatory component of inflammation in its broadest sense) is an intense or repeated cause of inflammation, the noxious stimulus itself. It stimulates inflammation but not the antiinflammatory response, the latter being only temporarily but not mechanistically related to the stimulus. On the other hand, factors that directly stimulate biochemical reactions of the anti-inflammatory response may do so even in the absence of previous inflammation, as shown for example in states of primary hypercorticism [59] or for peroxisome proliferator-activated receptor (PPAR) agonists [60, 61]. Besides the lack of discrimination of inflammation and antiinflammatory response, further sources of confusion in inflammation research were negligence of the true source of heat in inflammation (see above), as well as the concept that inflammation represents a reaction to any injury. These led to the development of an utterly wrong experimental model of inflammation, burns. With such a model, heat externally applied to a living tissue had been supposed to cause a process that would by all its characteristics be representative of inflammation [4, 27, 62]. According to the traditional notion of inflammation, it has been assumed that all four classic macroscopic signs may appear together in the course of an inflammatory process, and that eventual absence of some signs depends on variations in the intensity of the process. Three signs, i.e. rubor, calor and dolor, may appear in the course of burns (as defined by their obvious etiology). However, with burns edema never occurs, even in case of the most severe burns! This is evident from publicly available macroscopic presentations of burns in review articles [63, 64] as well as from published pictures of histologic sections of burnt tissue. Whereby, of course, one should not confuse blisters with edema. Specifically, a blister represents a continuous fluid collection placed between tissue layers, so that it could be completely evacuated by puncturing it. In contrast, edema is a fluid interspersed within the tissue that cannot be evacuated by a puncture, so that the tissue is both macroscopically and histologically expanded. While edema forms by attraction of water from primarily increased concentration of solutes, with burns water actually evaporates from the burnt tissue [65] and then condenses below the nearest hydrophobic, water impermeable layer, hence blisters. With second-degree burns such layer represents the dermoepidermal junction, with more severe burns it is the eschar. As the immediate consequence of such genesis of blisters, blister fluid is at least in the beginning with a poor protein content $[66,67]$ and probably hypo or normoosmolar. Burnt tissues show hypovolemia [68, 69] resulting from primary relative lack of water in the circulation. Based solely on the fact that there is no true edema with burns, one may conclude that: a) burns are not an inflammatory process at all, and b) three mentioned macroscopic signs appearing with burns are not specific for inflammation. The fact that proteolysis and catabolism in general are also inhibited by externally applied heat by reversion of the reaction thermodynamics (as is obvious from Eq. 1) makes burns and anti-inflammatory response fully compatible with each other, while putting burns in opposition to the inflammatory process. For a comparative review, processes representing integral components of inflammation, anti-inflammatory response and burns as an externally caused process opposite to inflammation are given in Table $\mathbf{1}$.

\section{CAUSES OF INFLAMMATION}

The principal cause of inflammation is a pure mechanical pressure, including blunt trauma [103,104], foreign bodies $[105,106]$, vibrations $[107,108]$ and chronic pressure of low intensity [109, 110]. The basic mechanism of causing inflammation by pressure is most probably through tissue hypoxia. Namely, tissue oxygen as a liposoluble substance is distributed mainly in lipids and hydrophobic proteinaceous matter. Exposed to pressure, the volume of tissue water and hydrophilic components as virtually incompressible remains unchanged, while hydrophobic matter is compressed, with oxygen being squeezed out. Upon cessation of pressure, due to its imperfect elasticity the tissue remains more or less shrunk and therefore with a significantly diminished oxygen content for a certain period. Concomitant vascular changes may contribute to hypoxia especially if larger blood vessels are involved. Hypoxia may then generate inflammatory changes through hypoxia-inducible factor (HIF) [125] and possibly other mediators, but the main mechanism may be the direct impairment of mitochondrially mediated anabolic processes and consequent metabolic shift towards catabolism, a process meeting the definition of inflammation presented above. 
Table 1. Contrasting Features of the Inflammatory Process, the Natural Anti-Inflammatory Response and the Process of Burns lammation Anti-inflammatory Response Burns

Appropriate references are given in brackets. When there are no available publications concerning a particular characteristic of a process, a reasonable guess is presented with a question mark. The list of etiological factors is not exhaustive, only common known causes of inflammation and burns are included. For each etiological factor of one of these two pathological processes, there is another factor on the other side of the table that directly counteracts the effect of the former in an inorganic medium

\begin{tabular}{|c|c|c|}
\hline Inflammation & Anti-Inflammatory Response & Burns \\
\hline \multicolumn{3}{|c|}{ Contrasting Phenomenological Features } \\
\hline Stimulated catabolism [45-53] & Catabolic inhibition $[70,71]$ & $\begin{array}{l}\text { Stimulated anabolic reactions [e.g. } \\
\text { gluconeogenesis] }[72,73]\end{array}$ \\
\hline Hypoxia [74-77] & Hypoxia? & $\begin{array}{l}\text { Enhanced oxidative metabolism [i.e. } \\
\text { "hypermetabolism"] [78-82] }\end{array}$ \\
\hline Hyperosmolarity $[38,41,43,44,83]$ & Hyperosmolarity? & Hypo- or normoosmolarity? \\
\hline Edema formation & Edema resolution & Blister or subeschar tissue fluid formation \\
\hline Necrosis [85-87] & $\begin{array}{c}\text { Conversion of a necrotic process to apoptotic cell } \\
\text { clearance [88-90] }\end{array}$ & Apoptosis [91-94] \\
\hline Lysis of colloids & & Coagulation of colloids \\
\hline Immunostimulation [95-97] & & Immunosuppression [98-102] \\
\hline Bases [116] & & Acids [117] \\
\hline Reducing substances $[118,119]$ & & Oxidative substances [120] \\
\hline Nucleophilic substances [121] & & Electrophilic substances [122] \\
\hline Exothermic substances [123] & & Endothermic substances [124] \\
\hline
\end{tabular}

The second most important physical inflammagenic factor is cold. Cold is a well recognized etiological factor of perniosis, a dermatitis upon cold exposure [114]. Also, cold may act through a frostbite [115]. In controlled experimental conditions, cooling is capable of causing inflammatory edema [126-128], in concordance with the ability of heat removal for stimulation of catabolism in Eq. (1). The common belief that exposure to cold at least predisposes to inflammatory conditions of infectious or noninfectious nature is therefore fully substantiated.

Of chemical etiological factors, one should note bases [116] and reducing substances [118, 119]. Effects of acids are at best controversial, having in mind their procoagulative and therefore burn-like activity. While impairment of oxidative pathways may be a common mechanism of action for reducing substances, bases cause direct hydrolysis of tissue constituents, favoring catabolism in a direct manner.

Inasmuch biocatalysts may be regarded as etiologic factors, one may mention proteolytic enzymes, other hydrolytic enzymes and, finally pathogenic microorganisms, that in a functional sense and in their relation to the host represent biocatalytic complexes with hydrolytic enzymes acting as their major factors of pathogenicity.

When assessing effects of chemical substances one should be very cautious since a single substance may carry different functional groups that could in different tissues react differently, sometimes even in opposed directions. For example, a substance may at the same time be reductive and acidic, oxidative and basic, etc. Also, a concentrated substance may influence the tissue in a purely physical way, by liberating or absorbing heat or adsorbing water. In particular, use of hydrophilic polymers such as carrageenan may first act by immediate water attraction, bringing about edema of non-inflammatory origin, that later may or may not be followed by inflammatory edema caused by the pressure made by the former. Therefore, for assessing biological effects one should be sure that a given substance reacts with the observed tissue by a completely determined mechanism.

\section{POSSIBLE ANTI-INFLAMMATORY STRATEGIES}

Once we confirm the biochemical essence of inflammation, what could we do to counteract it? Looking at Eq. (1), the process could in principle be reversed on a thermodynamic basis either by reducing any of the reactants on the right side or by enhancing those on the left. Direct change of substantial reactants is usually not desirable, since we principally want to preserve the organic structure that existed before the disruption of metabolic balance. In principle, each etiological factor that causes burns could be used as an anti-inflammatory agent. One therapeutic possibility that is apparent from the exposed equation is the addition of heat to the inflamed tissue. Thermotherapy has already been developed as a purely empirically based procedure [129], but for unknown reasons therapists have been reluctant to use this technique for treatment of acute inflammatory conditions. Thermotherapy could be done either by a myriad of physical modes of heat application, or by application of an endothermic substance that would release heat locally in a coupled reaction. Physical methods 
have the advantage of a relative ease of site selective heat delivery, while chemicals could usually be directed, except for topical application, only by local injection. Besides, the intensity of the action of a substance is absolutely limited by its maximal attainable concentration. On the other hand, chemical substances may more naturally act on inner mucosal surfaces of the gastrointestinal or respiratory tract. Both modalities (physical factors and chemicals) could of course be combined, if feasible. Preclinical studies would be needed to adjust the dosing regimen before adequate, carefully planned and controlled clinical trials are initiated. Thermotherapy alone may not be sufficient for extreme cases, but would on average enhance the overall therapeutic success rate without any danger of inducing burns and with an easily manageable risk of hyperthermia on a prolonged exposure. In cases where the cause of inflammation acted on a single occasion, anti-inflammatory therapy alone would be sufficient, but when the cause acts repeatedly or habitually additional measures are necessary to prevent its further action. In practical terms, one should well discriminate between true inflammation on one hand and burns or hyperthermia on the other. Diagnosis of true inflammation is unambiguously supported by the presence of catabolically generated edema as the only specific macroscopic sign. However, edema may be present only at a microscopic scale and sensitive noninvasive tests detecting the process or products of hydrolysis could be performed routinely. Because of the opposing nature of burns and inflammation, adequate therapeutic measures for burns should be quite different from the anti-inflammatory treatment.

Besides reversion of thermodynamics, one might also be guided by another therapeutic principle that is currently so widely used in pharmacotherapy, namely by catalysis regulatory action. Both principles could and should be properly applied for the optimal therapeutic effect.

Further, recognizing main etiological factors of inflammation may enable effective prophylactic measures to be taken especially in the course of therapeutic procedures. Thus, having in mind the paramount etiological importance of mechanical pressure, eventual introduction of a principle of acompression to surgical procedures may prove at least as important for prevention of sterile inflammation in surgical patients as the introduction of asepsis once proved. For example, instead of techniques that squeeze tissues during operative procedures, one could use vacuum-assisted instruments for tissue manipulation.

\section{CONCLUSIONS}

A comprehensive biochemical definition of inflammation is here proposed that is fully concordant with the most common facts and observations related to this pathological process. Inflammation is a special case of its closest more general phenomenon, degeneration, with the specific difference from all other degenerative processes being osmotically-mediated edema of catabolic origin. This pathological process arises as a direct consequence of a relevant injury and should be well differentiated to the opposing reactive process, the anti-inflammatory response and also regarded as opposite to burns as another important pathological process. This definition does not and cannot rely on any specific mediator of inflammation, since mediators as catalysts of the process, by analogy to chemical catalysts, do not define the process itself nor determine its direction. The presented definition should contribute to the basic, essential understanding of the inflammatory process. Once its important practical consequences are explored in detail, it should yield more effective anti-inflammatory therapeutic and prophylactic strategies.

\section{CONFLICT OF INTEREST}

The author confirms that this article content has no conflicts of interest.

\section{ACKNOWLEDGEMENT}

The author expresses his gratitude to the following voluntary reviewers for their valuable remarks and suggestions:

1. Prof. Alexander Boldyrev, Department of Biochemistry, School of Biology, MV Lomonosov Moscow State University, Moscow, Russia,

2. Prof. Dr. Artur Bauhofer, Institute of Theoretical Surgery, Philipps-University Marburg, Marburg, Germany,

3. Prof. Dr. Giuseppe Pintucci, Department of Cardiothoracic Surgery, New York University School of Medicine, New York, USA,

4. Prof. Dr. Ron Mathison, Faculty of Medicine, University of Calgary, Calgary, Canada, and

5. Prof. Dr. Dejan Cvjetković, Clinic for Infectious Diseases, Clinical Center of Vojvodina, Novi Sad, Serbia.

\section{REFERENCES}

[1] Suter E. The multiplication of tubercle bacilli within normal phagocytes in tissue culture. J Exp Med 1952; 96: 137-50.

[2] Horwitz MA, Silverstein SC. Legionnaires' disease bacterium (Legionella pneumophila) multiples intracellularly in human monocytes. J Clin Invest 1980; 66: 441-50.

[3] Harlow E, Lane D. Antibodies: a Laboratory manual. New York: Cold Spring Harbor Laboratory Press 1988.

[4] Ryan GB, Majno G. Acute inflammation. A review. Am J Pathol 1977; 86: 183-276.

[5] Definition of Inflammation. Available at: http://www.medter$\mathrm{ms} . \mathrm{com} / \mathrm{script} /$-main/art.asp?articlekey $=3979$ [Accessed January 24, 2010].

[6] Henson PM. Dampening inflammation. Nat Immunol 2005; 6: $1179-81$.

[7] Ye J, Keller JN. Regulation of energy metabolism by inflammation: a feedback response in obesity and calorie restriction. Aging (Albany NY) 2010; 2: 361-8.

[8] [No authors listed]. Get the balance right. Nat Immunol 2005; 6: 1177 .

[9] Rather LJ. Disturbance of function (functio laesa): the legendary fifth cardinal sign of inflammation, added by Galen to the four cardinal signs of Celsus. Bull NY Acad Med 1971; 47: 303-22.

[10] Majno G, Palade GE. Studies on inflammation. 1. The effect of histamine and serotonin on vascular permeability: an electron microscopic study. J Biophys Biochem Cytol 1961; 11: 571-605.

[11] Menkin V. Biochemical Mechanisms in Inflammation. Br Med J 1960; 1: 1521-8.

[12] Scott A, Khan KM, Cook JL, Duronio V. What is "inflammation"? Are we ready to move beyond Celsus? Br J Sports Med 2004; 38 : 248-9.

[13] Guyton AC. [Medical Physiology.] Medicinska knjiga: Beograd Zagreb, 1978. 
[14] Starling EH. On the absorption of fluids from the connective tissue spaces. J Physiol 1896; 19: 312-26.

[15] Fluid Physiology: 4.2 Starling's Hypothesis. Available at: http://www.anaesthe-siamcq.com/FluidBook/fl4_2.php [Accessed January 24, 2010].

[16] Schmiedl A, Schnabel PA, Richter J. Cellular edema and alterations in metabolite content in the ischemic and reperfused canine heart following different forms of cardiac arrest. Pathol Res Pract 1996; 192: 1163-78.

[17] Kuroiwa T, Miyasaka N, Fengyo Z, et al. Experimental ischemic brain edema: morphological and magnetic resonance imaging findings. Neurosurg Focus 2007; 22: E11.

[18] Yuan YH, Xiao EH, Liu JB, et al. Characteristics and pathological mechanism on magnetic resonance diffusionweighted imaging after chemoembolization in rabbit liver VX-2 tumor model. World J Gastroenterol 2007; 13: 5699-706.

[19] Simon M, Cleary TG, Hernandez JD, Abboud HE. Shiga toxin 1 elicits diverse biologic responses in mesangial cells. Kidney Int 1998; 54: 1117-27.

[20] Lee GJ, Chae SJ, Jeong JH, et al. Characterization of mitochondria isolated from normal and ischemic hearts in rats utilizing atomic force microscopy. Micron 2011; 42: 299-304.

[21] Torok B, Roth E, Trombitas K. Ultrastructural changes of the subendocardium in ischemic and cardioplegic states before and after reperfusion. Eur Surg Res 1982; 14: 17-26.

[22] Metcalf MF, McNeill JI, Kaufman HE. Experimental disciform edema and necrotizing keratitis in the rabbit. Invest Ophthalmol 1976; 15: 979-85.

[23] Polat ZA, Ozcelik S, Vural A, Yildiz E, Cetin A. Clinical and histologic evaluations of experimental Acanthamoeba keratitis. Parasitol Res 2007; 101: 1621-5.

[24] Jasin HE, Taurog JD. Mechanisms of disruption of the articular cartilage surface in inflammation. Neutrophil elastase increases availability of collagen type II epitopes for binding with antibody on the surface of articular cartilage. J Clin Invest 1991; 87: 1531-6.

[25] Jacobs JP, Pettit AR, Shinohara ML, et al. Lack of requirement of osteopontin for inflammation, bone erosion, and cartilage damage in the $\mathrm{K} / \mathrm{BxN}$ model of autoantibody-mediated arthritis. Arthritis Rheum 2004; 50: 2685-94.

[26] Hodgkin J, Kuwabara PE, Corneliussen B. A novel bacterial pathogen, Microbacterium nematophilum, induces morphological change in the nematode C. elegans. Curr Biol 2000; 10: 1615-8.

[27] Cotran RS, Majno G. The delayed and prolonged vascular leakage in inflammation. I. Topography of the leaking vessels after thermal injury. Am J Pathol 1964; 45: 261-81.

[28] Ferrara JJ, Dyess DL, Collins JN, et al. Effects of graded thermal injury on microvascular permeability at the site of injury. J Surg Res 1994; 57: 420-6.

[29] Segale M. The temperature of acutely inflamed peripheral tissue. J Exp Med 1919; 29: 235-49.

[30] Ciuraru NB, Braunstein R, Sulkes A, Stemmer SM. The influence of mucositis on oral thermometry: when fever may not reflect infection. Clin Infect Dis 2008; 46: 1859-63.

[31] Casscells W, Hathorn B, David M, et al. Thermal detection of cellular infiltrates in living atherosclerotic plaques: possible implications for plaque rupture and thrombosis. Lancet 1996; 347 : 1447-51.

[32] Stefanadis C, Diamantopoulos L, Dernellis J, et al. Heat production of atherosclerotic plaques and inflammation assessed by the acute phase proteins in acute coronary syndromes. J Mol Cell Cardiol 2000; 32: 43-52.

[33] Stefanadis C, Diamantopoulos L, Vlachopoulos C, et al. Thermal heterogeneity within human atherosclerotic coronary arteries detected in vivo: A new method of detection by application of a special thermography catheter. Circulation 1999; 99: 1965-71.

[34] Attur MG, Dave M, Akamatsu M, Katoh M, Amin AR. Osteoarthritis or osteoarthrosis: the definition of inflammation becomes a semantic issue in the genomic era of molecular medicine. Osteoarthritis Cartilage 2002; 10: 1-4.

[35] Wong D, Bazopoulou D, Pujol N, Tavernarakis N, Ewbank JJ. Genome-wide investigation reveals pathogen-specific and shared signatures in the response of Caenorhabditis elegans to infection. Genome Biol 2007; 8: R194.

[36] Wang Z, Shen W, Kotler DP, et al. Total body protein: a new cellular level mass and distribution prediction model. Am J Clin Nutr 2003; 78: 979-84.
[37] Ellis KJ. Human body composition: in vivo methods. Physiol Rev 2000; 80: 649-80.

[38] Schwartz L, Guais A, Pooya M, Abolhassani M. Is inflammation a consequence of extracellular hyperosmolarity? J Inflamm (Lond) 2009; 6: 21.

[39] Relova AJ, Roomans GM. Effect of luminal osmolarity on ion content of connective tissue in rat trachea after epithelial damage. Eur Respir J 2001; 18: 810-6.

[40] Jones JGW. The Biological Efficiency of Protein Production. Cambridge: Cambridge University Press 1973.

[41] Sakallioglu EE, Ayas B, Sakallioglu U, Acikgoz G, Caglayan F. Osmotic pressure and vasculature of gingiva in periodontal disease: an experimental study in rats. Arch Oral Biol 2006; 51: 505-11.

[42] Hallberg D. Hyperosmolality and trauma. Acta Anaesthesiol Scand Suppl 1974; 55: 21-7.

[43] Hatashita S, Hoff JT, Salamat SM. Ischemic brain edema and the osmotic gradient between blood and brain. J Cereb Blood Flow Metab 1988; 8: 552-9.

[44] Kawamata T, Mori T, Sato S, Katayama Y. Tissue hyperosmolality and brain edema in cerebral contusion. Neurosurg Focus 2007; 22: E5.

[45] Tiao G, Fagan JM, Samuels N, et al. Sepsis stimulates nonlysosomal, energy-dependent proteolysis and increases ubiquitin mRNA levels in rat skeletal muscle. J Clin Invest 1994; 94: 2255-64.

[46] Romisch J, Schuler E, Paques EP, Heimburger N. Hemostasis, fibrinolysis, proteolysis: interaction with inflammatory reactions. Behring Inst Mitt 1990; 86: 129-45.

[47] Fritz H, Jochum M, Geiger R, et al. Granulocyte proteinases as mediators of unspecific proteolysis in inflammation: a review. Folia Histochem Cytobiol 1986; 24: 99-115.

[48] Filkins JP. Monokines and the metabolic pathophysiology of septic shock. Fed Proc 1985; 44: 300-4.

[49] Todd JK, Franco-Buff A, Lawellin DW, Vasil ML. Phenotypic distinctiveness of Staphylococcus aureus strains associated with toxic shock syndrome. Infect Immun 1984; 45: 339-44.

[50] Vassalli JD, Granelli-Piperno A, Reich E. Neutral proteinases of leucocytes and the inflammatory process. CIBA Found Symp 1979; 381-95.

[51] Finn PJ, Plank LD, Clark MA, Connolly AB, Hill GL. Progressive cellular dehydration and proteolysis in critically ill patients. Lancet 1996; 347: 654-6.

[52] Nogueira-Filho G, Xiang XM, Shibli JA, et al. On site noninvasive assessment of peri-implant inflammation by optical spectroscopy. J Periodontal Res 2011; 46: 382-8.

[53] Haramizu S, Ota N, Hase T, Murase T. Aging-associated changes in physical performance and energy metabolism in the senescenceaccelerated mouse. J Gerontol A Biol Sci Med Sci 2011; 66: 64655.

[54] Opie EL. On the relation of inflammation to the chemical constitution of injurious agents. On the pharmacology of inflammation. J Exp Med 1963; 117: 425-48.

[55] Tauber AI. Metchnikoff and the phagocytosis theory. Nat Rev Mol Cell Biol 2003; 4: 897-901.

[56] Hiemstra PS. Novel roles of protease inhibitors in infection and inflammation. Biochem Soc Trans 2002; 30: 116-20.

[57] Chu AJ. Tissue factor upregulation drives a thrombosisinflammation circuit in relation to cardiovascular complications. Cell Biochem Funct 2006; 24: 173-92.

[58] Han JI. Urinary trypsin inhibitor: miraculous medicine in many surgical situations? Korean J Anesthesiol 2010; 58: 325-7.

[59] Stratakis CA. Cushing syndrome caused by adrenocortical tumors and hyperplasias (corticotropin-independent Cushing syndrome). Endocr Dev 2008; 13: 117-32.

[60] Burns KA, Vanden Heuvel JP. Modulation of PPAR activity via phosphorylation. Biochim Biophys Acta 2007; 1771: 952-60.

[61] Sharifpanah F, Wartenberg M, Hannig M, Piper HM, Sauer H. Peroxisome proliferator-activated receptor alpha agonists enhance cardiomyogenesis of mouse ES cells by utilization of a reactive oxygen speciesdependent mechanism. Stem Cells 2008; 26: 64-71.

[62] Cotran RS. The delayed and prolonged vascular leakage in inflammation.II. An electron microscopic study of the vascular response after thermal injury. Am J Pathol 1965; 46: 589-620.

[63] Benson A, Dickson WA, Boyce DE. Burns. BMJ 2006; 332: 64952 . 
[64] Hettiaratchy S, Dziewulski P. ABC of burns: pathophysiology and types of burns. BMJ 2004; 328: 1427-9.

[65] Jelenko C, III. Studies in burns. I. Water loss from the body surface. Ann Surg 1967; 165: 83-96.

[66] Demling RH, Will JA, Belzer FO. Effect of major thermal injury on the pulmonary microcirculation. Surgery $1978 ; 83: 746-51$.

[67] Green KL. Quantitative studies on the accumulation of serum albumin and erythrocytes in mouse paw oedema induced by bradykinin or thermal injury. Br J Exp Pathol 1978; 59: 38-47.

[68] Blanchet B, Jullien V, Vinsonneau C, Tod M. Influence of burns on pharmacokinetics and pharmacodynamics of drugs used in the care of burn patients. Clin Pharmacokinet 2008; 47: 635-54.

[69] Shirani KZ, Vaughan GM, Mason AD Jr, Pruitt BA Jr. Update on current therapeutic approaches in burns. Shock 1996; 5: 4-16.

[70] Nakagawa H, Watanabe K, Tsurufuji S. Changes in serum and exudate levels of functional macroglobulins and anti-inflammatory effect of alpha 2-acute-phase macroglobulin on carrageenininduced inflammation in rats. Biochem Pharmacol 1984; 33: 11816.

[71] Abrams WR, Fein AM, Kucich U, et al. Proteinase inhibitory function in inflammatory lung disease. I. Acute bacterial pneumonia. Am Rev Respir Dis 1984; 129: 735-41.

[72] Tredget EE, Yu YM. The metabolic effects of thermal injury. World J Surg 1992; 16: 68-79.

[73] Yu YM, Tompkins RG, Ryan CM, Young VR. The metabolic basis of the increase of the increase in energy expenditure in severely burned patients. J Parenter Enteral Nutr 1999; 23: 160-8.

[74] Koeppen M, Eckle T, Eltzschig HK. The hypoxia-inflammation link and potential drug targets. Curr Opin Anaesthesiol 2011; 24: 363-9.

[75] Taylor CT. Interdependent roles for hypoxia inducible factor and nuclear factor-kappaB in hypoxic inflammation. J Physiol 2008; 586: 4055-9.

[76] Schwartzman ML, Bonazzi A, Mieyal P, Mezentsev A, Abraham NG, Dunn MW. COX-2 lack of function in hypoxia-induced ocular surface inflammation. Thromb Res 2003; 110: 293-8.

[77] Feng J, Wang QS, Chiang A, Chen BY. The effects of sleep hypoxia on coagulant factors and hepatic inflammation in emphysematous rats. PLoS One 2010; 5: e13201.

[78] Williams FN, Herndon DN, Suman OE, et al. Changes in cardiac physiology after severe burn injury. J Burn Care Res 2011; 32: 269-74.

[79] Aizawa K, Sato S, Saitoh D, Ashida H, Obara M. Photoacoustic monitoring of burn healing process in rats. J Biomed Opt 2008; 13: 064020.

[80] Jeschke MG, Gauglitz GG, Kulp GA, et al. Long-term persistance of the pathophysiologic response to severe burn injury. PLoS One 2011; 6: e21245.

[81] Jeschke MG, Mlcak RP, Finnerty CC, et al. Burn size determines the inflammatory and hypermetabolic response. Crit Care 2007; 11: R90.

[82] Barrow RE, Meyer NA, Jeschke MG. Effect of varying burn sizes and ambient temperature on the hypermetabolic rate in thermally injured rats. J Surg Res 2001; 99: 253-7.

[83] Bandaranayake NM, Nemoto EM, Stezoski SW. Rat brain osmolality during barbiturate anesthesia and global brain ischemia. Stroke 1978; 9: 249-54.

[84] Majno G, Palade GE, Schoefl GI. Studies on inflammation. II. The site of action of histamine and serotonin along the vascular tree: a topographic study. J Biophys Biochem Cytol 1961; 11: 607- 26.

[85] Li H, Ambade A, Re F. Cutting edge: Necrosis activates the NLRP3 inflammasome. J Immunol 2009; 183: 1528-32.

[86] Rock KL, Kono H. The inflammatory response to cell death. Ann Rev Pathol 2008; 3: 99-126.

[87] Scaffidi P, Misteli T, Bianchi ME. Release of chromatin protein HMGB1 by necrotic cells triggers inflammation. Nature 2002; 418 : $191-5$.

[88] Huynh ML, Fadok VA, Henson PM. Phosphatidylserine-dependent ingestion of apoptotic cells promotes TGF-betal secretion and the resolution of inflammation. J Clin Invest 2002; 109: 41-50.

[89] Elliott MR, Ravichandran KS. Clearance of apoptotic cells: implications in health and disease. J Cell Biol 2010; 189: 1059-70.

[90] Krysko DV, D'Herde K, Vandenabeele P. Clearance of apoptotic and necrotic cells and its immunological consequences. Apoptosis 2006; 11: 1709-26.
[91] Jeschke MG, Low JF, Spies M, et al. Cell proliferation, apoptosis, NF-kappaB expression, enzyme, protein, and weight changes in livers of burned rats. Am J Physiol Gastrointest Liver Physiol 2001; 280: G1314-20.

[92] Ramzy PI, Wolf SE, Irtun O, Hart DW, Thompson JC, Herndon DN. Gut epithelial apoptosis after severe burn: effects of gut hypoperfusion. J Am Coll Surg 2000; 190: 281-7.

[93] Wolf SE, Ikeda H, Matin S, et al. Cutaneous burn increases apoptosis in the gut epithelium of mice. J Am Coll Surg 1999; 188: $10-6$.

[94] Lightfoot E Jr, Horton JW, Maass DL, White DJ, McFarland RD, Lipsky PE. Major burn trauma in rats promotes cardiac and gastrointestinal apoptosis. Shock 1999; 11: 29-34

[95] Urbonaviciute V, Furnrohr BG, Meister S, et al. Induction of inflammatory and immune responses by HMGB1-nucleosome complexes: implications for the pathogenesis of SLE. J Exp Med 2008; 205: 3007-18

[96] Hoogerwerf JJ, de Vos AF, Bresser P, et al. Lung inflammation induced by lipoteichoic acid or lipopolysaccharide in humans. Am J Respir Crit Care Med 2008; 178: 34-41.

[97] Kimbrell MR, Warshakoon H, Cromer JR, et al. Comparison of the immunostimulatory and proinflammatory activities of candidate Gram-positive endotoxins, lipoteichoic acid, peptidoglycan, and lipopeptides, in murine and human cells. Immunol Lett 2008; 118: 132-41.

[98] Robins EV. Immunosuppression of the burned patient. Crit Care Nurs Clin North Am 1989; 1: 767-74.

[99] Ortega MR, Ganz T, Milner SM. Human beta defensin is absent in burn blister fluid. Burns 2000; 26: 724-6.

[100] Deitch EA. Opsonic activity of blister fluid from burn patients. Infect Immun 1983; 41: 1184-9.

[101] Shaked G, Gurfinkel R, Czeiger D, Douvdevani A, Sufaro Y Adenosine in burn blister fluid. Burns 2007; 33: 352-4.

[102] Alexander M, Chaudry IH, Schwacha MG. Relationships between burn size, immunosuppression, and macrophage hyperactivity in a murine model of thermal injury. Cell Immunol 2002; 220: 63-9.

[103] Cohen MJ, Brohi K, Calfee CS, et al. Early release of high mobility group box nuclear protein 1 after severe trauma in humans: role of injury severity and tissue hypoperfusion. Crit Care 2009; 13: R174.

[104] Ramlackhansingh AF, Brooks DJ, Greenwood RJ, et al. Inflammation after trauma: Microglial activation and traumatic brain injury. Ann Neurol 2011; 70: 374-83.

[105] Subramanian R, White CJ, Sternbergh WC, III, Ferguson DL Gilchrist IC. Nonhealing wound resulting from a foreign-body reaction to a radial arterial sheath. Catheter Cardiovasc Interv 2003; 59: 205-6.

[106] Auquit-Auckbur I, Caillot F, Arnoult C, et al. Role of toll-like receptor 4 in the inflammation reaction surrounding silicone prosthesis. Acta Biomater 2011; 7: 2047-52.

[107] Abi-Hachem RN, Zine A, Van De Water TR. The injured cochlea as a target for inflammatory processes, initiation of cell death pathways and application of related otoprotectives strategies. Recent Pat CNS. Drug Discov 2010; 5: 147-63.

[108] Dina OA, Joseph EK, Levine JD, Green PG. Mechanisms mediating vibration-induced chronic musculoskeletal pain analyzed in the rat. J Pain 2010; 11: 369-77.

[109] Davis BA, Handy CA. Cellulitis--an unreported complication of longterm SCI patients. SCI Nurs 1996; 13: 35-8.

[110] New PW, Rawicki HB, Bailey MJ. Nontraumatic spinal cord injury rehabilitation: pressure ulcer patterns, prediction, and impact. Arch Phys Med Rehabil 2004; 85: 87-93.

[111] Hemington-Gorse SJ, Slattery MA, Drew PJ. Burns related to sunbed use. Burns 2010; 36: 920-3.

[112] Fleck H. Microwave oven burn. Bull NY Acad Med 1983; 59: 313 7.

[113] Coggle JE. Biological effects of radiation. London and Winchester: Wykeham Publications 1973.

[114] Cribier B, Djeridi N, Peltre B, Grosshans E. A histologic and immunohistochemical study of chilblains. J Am Acad Dermatol 2001; 45: 924-9.

[115] Taylor KR, Yamasaki K, Radek KA, et al. Recognition of hyaluronan released in sterile injury involves a unique receptor complex dependent on Toll-like receptor 4, CD44, and MD-2. J Biol Chem 2007; 282: 18265-75. 
[116] Sennlaub F, Courtois Y, Goureau O. Nitric oxide synthase-II is expressed in severe corneal alkali burns and inhibits neovascularization. Invest Ophthalmol Vis Sci 1999; 40: 2773-9.

[117] Burgher F, Mathieu L, Lati E, et al. Experimental $70 \%$ hydrofluoric acid burns: histological observations in an established human skin explants ex vivo model. Cutan Ocul Toxicol 2011; 30: 100-7.

[118] Nowak NM, Fischer OM, Gust TC, Fuhrmann U, Habenicht UF, Schmidt A. Intraperitoneal inflammation decreases endometriosis in a mouse model. Hum Reprod 2008; 23: 2466-74.

[119] Collins RG, Jung U, Ramirez M, et al. Dermal and pulmonary inflammatory disease in E-selectin and P-selectin double-null mice is reduced in triple-selectin-null mice. Blood 2001; 98: 727-35.

[120] Watt BE, Proudfoot AT, Vale JA. Hydrogen peroxide poisoning. Toxicol Rev 2004; 23: 51-7.

[121] Jones H, Paul W, Page CP. A comparison of allergen and polycation induced cutaneous responses in the rabbit. $\mathrm{Br} \mathrm{J}$ Pharmacol 2001; 133: 1181-9.

[122] Smith KJ, Smith WJ, Hamilton T, et al. Histopathologic and immunohistochemical features in human skin after exposure to nitrogen and sulfur mustard. Am J Dermatopathol 1998; 20: 22-8.
[123] Urbain B, Gustin P, Prouvost JF, Ansay M. Quantitative assessment of aerial ammonia toxicity to the nasal mucosa by use of the nasal lavage method in pigs. Am J Vet Res 1994; 55: 133540.

[124] Morritt AN, Bache SE, Ralston D, Stephenson AJ. Coal ash poultice: an unusual cause of a chemical burn. J Burn Care Res 2009; 30: 1046-7.

[125] Adams JM, Difazio LT, Rolandelli RH, et al. HIF-1: a key mediator in hypoxia. Acta Physiol Hung 2009; 96: 19-28.

[126] Bruneau J, Heinbecker P. Effects of Cooling on Experimentally Infected Tissues. Ann Surg 1944; 120: 716-26.

[127] Karalova EM, Gabrielian NA, Kanaian AS, Magakian I Morphofunctional changes in the exocrine pancreatic cells in acute experimental pancreatitis in rats. Tsitologiia 1990; 32: 337-42.

[128] Tveita T, Johansen K, Lien AH, Myklebust R, Lindal S. Morphologic changes in tubular cells from in situ kidneys following experimental hypothermia and rewarming. APMIS 2005; 113: 13-20.

[129] Goats GC. Microwave diathermy. Br J Sports Med 1990; 24: 2128.

(C) Srđan V. Stankov; Licensee Bentham Open.

This is an open access article licensed under the terms of the Creative Commons Attribution Non-Commercial License (http://creativecommons.org/licenses/by$\mathrm{nc} / 3.0 /$ ), which permits unrestricted, non-commercial use, distribution and reproduction in any medium, provided the work is properly cited. 